Research Article

\title{
Knowledge, Attitudes, Practices of farmers exposed to pesticides at Banikoara Township (Republic of Benin)
}

\author{
Hinson, A.V ${ }^{1^{*}}$, Lawin, $\mathbf{H}^{1}$, Gounongbe, $\mathbf{F}^{2}$, Dossou, $\mathrm{F}^{1}$, Fayomi, $\mathrm{B}^{1}$ \\ ${ }^{1}$ Unity of Teaching and Research in Occupational Health, University of Abomey-Calavi (Benin) \\ ${ }^{2}$ Unity of Teaching and Research in Occupational Health, University of Parakou (Benin).
}

*Corresponding authors: Hinson, A.V., Unity of Teaching and Research in Occupational Health, University of Abomey-Calavi (Benin). E-mail: hinsvikkey@yahoo.fr

\begin{abstract}
The aim of the study was to assess the knowledge, attitude and practice of the farmers related to the pesticides use in a zone of strong use in Benin.

Method: it was a descriptive and cross sectional study which focuses on adult and teenagers of both gender living in Banikoara district. By a random sampling 384 farmers were selected. The data collected have been processed and analyzed using Excel 2007 and Epi-Info Version 3.5.1. The results of the quantitative variables are presented as mean $\pm \mathrm{SD}$ and categorical variables such as percentage. Categorical variables are compared using chi-square tests.

Results: The average age was $36.5 \pm 10.6$ years old. $52.1 \%$ of respondents reported that they were able to recognize their packaging without pesticides, $53.4 \%$ from their forms and $65.2 \%$ by labeled and know their meaning. Approximately $75 \%$ of the respondents reported having been trained on more than one occasion pesticides. Nevertheless, only $13.2 \%$ of respondents were storing pesticides in stores dedicated solely to pesticides. None of the respondents do not use protective mask. Literacy and membership in farmers' organization have an impact on the recognition of the labeled pesticides, knowledge of the importance of labeling, knowledge of the meaning of the symbols, storage in a single pesticide store. But they are not for storage in the bedroom.

Conclusion: Management of toxic risk relating to pesticides handling in our study area is dependent on human factors: in terms of risk awareness and good storage practices and handling.
\end{abstract}

Keywords: Pesticides; Poisoning; KAP study; Benin

\section{Introduction}

Intensive agricultural practices in Benin since the fifties have led to a widespread use of organic pesticides ${ }^{[1]}$. Unfortunately, the use of pesticide is not without consequences for human health and the ecosystems ${ }^{[2]}$. According to the World Health Organization (WHO), "Every year, there are reportedly 1.5 million cases of pesticide poisoning resulting in the deaths of thousands of farmers and children in Africa. Although African countries import less than $10 \%$ of pesticides used in the world, it is reported that this import accounts for half of accidental poisonings and over $75 \%$ of fatal cases"[3]. Between May and September 1999, 73 cases of severe poisoning were reported in Benin by Callisulfan (Endosulfan 350g) including 37 deaths in the department of Borgou in Benin ${ }^{[4]}$. Badarou S. Coppieters registered between May 2007 and July 2008, 105 cases of poisoning among which 9 deaths were due to the Endosulfan ${ }^{[5]}$. Our country is still at record levels of harmful effects of these products on human health and the environment. The reasons for this situation may be linked

\author{
Received Date: April 24, 2015 \\ Accepted Date: July 01, 2015 \\ Published Date: July 07, 2015
}

Citation: Hinson, A.V., et al. Knowledge, Attitudes, Practices of farmers exposed to pesticides at Banikoara Township (Republic of Benin). (2015) J Environ Health Sci 1(2): 1-5.

DOI: $10.15436 / 2378-6841.15 .013$

to human factors (knowledge, attitudes and practices) that could be very crucial in the management of toxic risk associated with the handling and use of pesticides in Benin. Although several previous studies have already addressed the issue of the impact of pesticides on human health and the risks of eco-systemic pollution in Benin, the effectiveness of the current risks management systems ( i.e., its strengths and weaknesses), has not been sufficiently addressed. The sustainability of farming which heavily depends on the use of pesticides, as well as its economic advantages can never be achieved unless the ecosystems and the health of workers are preserved. If it won't be a question of banishing pesticides, it will however be necessary to find a just balance between the necessity of their uses and the imperatives of health prevention and environmental protection.

The objective of this study is to:

1. Identify pesticides used in the area covered by the study.

2. Appreciate the knowledge, attitudes, and practices regarding the use of pesticides by farmers and the management of the empties containers.

Copy rights: (C2015 Hinson, A.V. This is an Open access article distributed under the terms of Creative Commons Attribution 4.0 International License. 


\section{Methods}

This is a descriptive observational, exploratory and cross sectional study which focusses on adult and teenagers of both gender of the Banikoara district. This target population practice agricultural activity involving intensive use of pesticides. Banikoara is the biggest cotton production city in Benin. Producers, rural development and health workers involved in pesticide risks have been taken into account in the sampled population.

Sample size: With a prevalence of 0.5 , a precision of $0.5 \%$ and error risk of $5 \%$, the sample size was determined using the Schwartz formula, and $n=384$ was subjects. To compensate for the refusal or resignations " $n$ " was weighted by $t=1.10 \mathrm{~s}=422$ surveyed persons in total.

Sampling: We conducted a random sampling of farmers, health workers and rural development agents. Farmers were involved in the study in a probabilistic way using a simple random sampling. Others involved in the pesticides risk management, such as health workers and rural development agents were systematically taken into account in the study.

Data Collection: The previously trained to administer the questionnaire and the use of the interview guide investigators participated in the data collection. Data on producers were collected using questionnaires with individual interviews. The rural development officers and health workers have been individual interviews with service guides. Counting cards have collected the records of care, clinical information and statistics from health facilities.

Data analysis: The data collected have been processed and analyzed using Excel 2007 and Epi-Info Version 3.5.1 software. The results of the quantitative variables were presented as mean \pm standard deviation and categorical variables such as percentage form. The strength of association was appreciated by OR with his CI. Categorical variables were compared using Chi-2 tests Mantel-Haenszel. The significance level chosen for all statistical analyzes was 0.05 .

\section{Results}

Distribution of population depending on age, gender and level of education

The average age was $36.5 \pm 10.6$ years old. The highest age ranges from 15 and 70 years. Men outnumber women with a sex ratio of 18.22 . The majority of respondents are illiterate $(80.3 \%)$ as indicated.

Table 1: Distribution of population depending on age, gender andlevel of education

\begin{tabular}{|c|c|c|}
\hline Items & Number & $\%$ \\
\hline \multicolumn{3}{|l|}{ Ages brackets } \\
\hline $15-18$ & 4 & 0.9 \\
\hline $18-50$ & 370 & 87.5 \\
\hline $50-70$ & 49 & 11.6 \\
\hline \multicolumn{3}{|l|}{ Gender } \\
\hline Female & 22 & 5.2 \\
\hline Male & 401 & 94.8 \\
\hline \multicolumn{3}{|l|}{ Instruction } \\
\hline Yes & 83 & 19.7 \\
\hline No & 339 & 80.3 \\
\hline
\end{tabular}

Pesticides used during the study period (active ingredients, WHO classification)

Insecticides and herbicides are among the most used pesticides identified

Table 2: Pesticides used during the study period (active ingredients, WHO classification)

\begin{tabular}{|c|c|c|c|}
\hline No. & $\begin{array}{l}\text { Trade } \\
\text { name }\end{array}$ & Active ingredient (ICD) & $\begin{array}{l}\text { Toxicity } \\
\text { WHO }\end{array}$ \\
\hline \multicolumn{4}{|c|}{ INSECTICIDES } \\
\hline $1 *$ & Proclaim & TEFLUBENZURON & \\
\hline $2 *$ & Cutter & $\begin{array}{l}\text { EMAMECTINE 48EC+ACETAMIPRID } \\
64 \mathrm{EC}\end{array}$ & \\
\hline 3 & Emacot & EMAMECTINE & \\
\hline 4 & Protet & EMAMECTINE & \\
\hline 5 & Caïman & EMAMECTINE & \\
\hline 6 & Fanga & PROFENOFOS & II \\
\hline 7 & Calfos & PROFENOFOS & II \\
\hline 8 & Profenet & PROFENOFOS & II \\
\hline 9 & Tenor & PROFENOFOS & II \\
\hline 10 & Calife & PROFENOFOS & II \\
\hline 11 & Ema super & $\begin{array}{l}\text { EMAMECTINE 24EC+ACETAMIPRID } \\
\text { 32EC }\end{array}$ & \\
\hline 12 & Stewar & INDOXACARB & \\
\hline 13 & Cobra & SPINETORAME+ACETAMIPRID & \\
\hline 14 & Nurelle d & CYPERMETHRINE+CHLOREPYRIPHOS & \\
\hline 15 & Cotalmp & $\begin{array}{l}\text { LAMBDACYHALOTHRINE+PROFENO- } \\
\text { FOS }\end{array}$ & II \\
\hline $16^{*}$ & Kd plus & $\begin{array}{l}\text { LAMBDACYHALO- } \\
\text { THRINE+CHLOREPYRIPHOS }\end{array}$ & II \\
\hline $17^{*}$ & Acetastar & BIVENTHRINE+ACETAMIPRID & II \\
\hline $18^{*}$ & Acetastar & BIVENTHRINE+ACETAMIPRID & II \\
\hline 19 & Chemaprid & CYPERMETHRINE+ACETAMIPRID & II \\
\hline 20 & Conquest & CYPERMETHRINE+ACETAMIPRID & II \\
\hline 21 & Capt & CYPERMETHRINE+ACETAMIPRID & II \\
\hline 22 & Phoenix & CYPERMETHRINE+ACETAMIPRID & II \\
\hline $23 * *$ & Koptimal & $\begin{array}{l}\text { LAMBDACIALOTHRINE+ACETAMI- } \\
\text { PRID }\end{array}$ & II \\
\hline $24 * *$ & Koptimal & $\begin{array}{l}\text { LAMBDACIALOTHRINE+ACETAMI- } \\
\text { PRID }\end{array}$ & II \\
\hline $25^{* *}$ & Koptimal & $\begin{array}{l}\text { LAMBDACIALOTHRINE+ACETAMI- } \\
\text { PRID }\end{array}$ & II \\
\hline $26^{* *}$ & Lamprid & $\begin{array}{l}\text { LAMBDACIALOTHRINE+ACETAMI- } \\
\text { PRID }\end{array}$ & II \\
\hline $27 * *$ & Sting & CYPERMETHRINE+ DIMETOATE & \\
\hline 28 & Thian & & \\
\hline 29 & Thunder & & \\
\hline 30 & Sherphos & & \\
\hline \multicolumn{4}{|c|}{ HERBICIDES } \\
\hline 31 & Garil & Triclopyr+propanil & \\
\hline 32 & $\begin{array}{l}\text { Calif } \\
\text { (cotton) }\end{array}$ & & \\
\hline 33 & $\begin{array}{c}\text { Kalach } \\
\text { (total) }\end{array}$ & & \\
\hline 34 & $\begin{array}{l}\text { Lagon } \\
\text { (maize) }\end{array}$ & & \\
\hline
\end{tabular}

*Pesticides of which, the trade names are not found in the national authorized pesticides but whose active ingredients are covered in part or entirely under other trade names. 
**Pesticides among which neither the trade names nor the associations of the active ingredient such as presented are not found in the official list of authorized pesticides.

Knowledge, attitudes and practices of the producers regarding the pesticides pictogram or label and the reason of use

$52.1 \%$ of respondents reported that they were able to recognize their packaging without pesticides, $53.4 \%$ from their forms and $65.2 \%$ by labeled and know their meaning. Furthermore, $87.5 \%$ of respondents were aware of the risks against $71.2 \%$ and $68.1 \%$ respectively for the risks to the air and water.

Table 3: Knowledge, attitudes and practices of the producers regarding the pesticides pictogram or label and the reason of use

\begin{tabular}{|c|c|c|}
\hline Items & Number & $\%$ \\
\hline \multicolumn{3}{|c|}{ Recognizing pesticides without package } \\
\hline Yes & 220 & 52.1 \\
\hline No & 202 & 47.9 \\
\hline \multicolumn{3}{|c|}{ Recognizing pesticides with package but by: } \\
\hline Odor & 218 & 51.5 \\
\hline Color & 5 & 1.2 \\
\hline \multicolumn{3}{|c|}{ Recognizing pesticides with packages but by : } \\
\hline Form of the package & 226 & 53.4 \\
\hline Labels on the package & 276 & 65.2 \\
\hline \multicolumn{3}{|c|}{ Knowledge of the significance of images on the labels : } \\
\hline Yes & 275 & 65.2 \\
\hline No & 147 & 34.8 \\
\hline \multicolumn{3}{|c|}{ Awareness of intoxication cases } \\
\hline Yes & 394 & 93.8 \\
\hline No & 26 & 6.2 \\
\hline
\end{tabular}

Awareness of the level of toxicity according to the source of supply :

\begin{tabular}{|l|c|c|}
\hline Official plus toxicity & 3 & 0.7 \\
\hline Informal plus toxic & 252 & 59.6 \\
\hline Same toxicity & 165 & 39.0 \\
\hline
\end{tabular}

Reasons given to justify the use of pesticides in spite of their toxicity:

\begin{tabular}{|l|l|l|}
\hline Improve crop yield & 317 & 74.9 \\
\hline Facilitate work & 317 & 74.9 \\
\hline Fighting crop parasites & 355 & 83.9 \\
\hline
\end{tabular}

Knowledge, attitudes and practices of the producers concerning the pesticides storage, management of empty package and precaution of use

Only $13.2 \%$ of the investigated stored pesticides in stores dedicated only to pesticides. The majority of respondents reused empty containers. $69.3 \%$ investigated are asserted that they took no precaution regarding protection before treating pesticides. None of the investigated uses a protective mask .

Table 4: Knowledge, attitudes and practices of the producers regarding the pesticides storage, management of empty package and precaution of use

\begin{tabular}{|l|l|l|}
\hline Variables & Number & $\%$ \\
\hline Storage place of pesticides & 24 & 5.7 \\
\hline Home & 209 & 49.4 \\
\hline Bedroom & 5 & 1.2 \\
\hline Kitchen & 161 & 38.1 \\
\hline Common warehouse & 56 & 13.2 \\
\hline Only in pesticides storeroom & & \\
\hline
\end{tabular}

\begin{tabular}{|c|c|c|}
\hline Farms & 20 & 4.7 \\
\hline \multicolumn{3}{|c|}{ Management of empty packages } \\
\hline Re-use & 375 & 88.7 \\
\hline Sell & 230 & 54.4 \\
\hline Throw away & 175 & 41.4 \\
\hline Bury & 7 & 1.7 \\
\hline Burn & 7 & 1.7 \\
\hline \multicolumn{3}{|l|}{ Caution of use } \\
\hline Nothing at all & 293 & 69.3 \\
\hline Bibs & 72 & 17 \\
\hline Hide nose & 118 & 29.9 \\
\hline Mask & 00 & 00 \\
\hline Face protection equipment & 16 & 3.8 \\
\hline Protective clothing & 16 & 3.8 \\
\hline Gloves & 52 & 12.3 \\
\hline Boots & 21 & 5 \\
\hline Eyes glasses & 11 & 2.6 \\
\hline
\end{tabular}

Distribution of respondents depending on the training they received and training organizations

Handling and spraying techniques were most taught $93.3 \%$. The behavior one should have in case of acute intoxication $(43.5 \%)$ and management of waste and empty containers (42.1\%) followed respectively. Approximate$1 y, 3 / 4^{\text {th }}$ of the respondents reported having been trained on more than one occasion pesticides. Health agents had intervened in the trainings only for less than $1 \%$ investigated.

Table 5: Distribution of respondents depending on the training they received and training organizations

\begin{tabular}{|c|c|c|}
\hline Items & Total (Number) & $\%$ \\
\hline \multicolumn{3}{|l|}{ Training Themes } \\
\hline Identification of pesticides & 85 & 20,1 \\
\hline Dangerousness of pesticides & 79 & 18,7 \\
\hline $\begin{array}{l}\text { Management of empty packages and the residues } \\
\text { of pesticides }\end{array}$ & 178 & 42,1 \\
\hline Behavior to have in case of acute intoxication & 184 & 43,5 \\
\hline Handling and spraying techniques & 416 & 98,3 \\
\hline Reporting information on acute intoxication & 23 & 5,4 \\
\hline \multicolumn{3}{|l|}{ Number of training received } \\
\hline One training session & 110 & 26 \\
\hline More than one training session & 308 & 72,8 \\
\hline \multicolumn{3}{|l|}{ Organizations having trained /informed } \\
\hline Health agents & 2 & 0,5 \\
\hline Rural development agents & 408 & 96,5 \\
\hline Fertilizers distribution & 65 & 15,4 \\
\hline NGOs & 2 & 0,5 \\
\hline The Media & 38 & 9 \\
\hline
\end{tabular}

Risk factors of poisoning: knowledge and practice versus/ education, membership to farmers organizations, risks on human being.

The instruction and membership in farmers' organization have an impact on the recognition of the labeled pesticides, knowledge of the importance of labeling, of the meaning of the pictogram, of the storage in a single pesticide store. But they are not for storage in the bedroom. 
All the same, awareness of the risks for humans had no influence on the storage in a specific pesticides warehouse.

Table 6: Risk factors of poisoning: knowledge and practice versus/education, membership to farmers organizations, risks on human being.

\begin{tabular}{|c|c|c|c|}
\hline Items & & OR (IC 95\%) & $\mathbf{P}$ \\
\hline \multirow{5}{*}{$\begin{array}{l}\text { Education : } \\
\text { yes Vs No }\end{array}$} & Knowledge by labels: Yes & $\begin{array}{l}9,1389 \quad[3,87 ; \\
21,56]\end{array}$ & $<0,05$ \\
\hline & $\begin{array}{l}\text { Knowledge of label im- } \\
\text { portance: Yes }\end{array}$ & $\begin{array}{l}22,12 \quad[5,34 ; \\
91,6]\end{array}$ & $<0,05$ \\
\hline & $\begin{array}{l}\text { Knowledge of pictogram } \\
\text { meaning: Yes }\end{array}$ & $\begin{array}{l}19,79 \\
63,94]\end{array} \quad[6,12 ;$ & $<0,05$ \\
\hline & $\begin{array}{l}\text { Storage in specific store: } \\
\text { Yes }\end{array}$ & $\begin{array}{l}68,3 \quad[28,7 ; \\
162,6]\end{array}$ & $<0,05$ \\
\hline & Storage in room: Yes & $\begin{array}{l}0,25 \quad[0,14 ; \\
0,43]\end{array}$ & $<0,05$ \\
\hline \multirow{5}{*}{$\begin{array}{l}\text { Membership to } \\
\text { farmers } \\
\text { organizations : } \\
\text { Yes Vs No }\end{array}$} & Knowledge by labels: Yes & $\begin{array}{l}27,76 \quad[6,7 ; \\
114,9]\end{array}$ & $<0,05$ \\
\hline & $\begin{array}{l}\text { Knowledge of label im- } \\
\text { portance: Yes }\end{array}$ & $\begin{array}{l}41,73 \quad[5,73 ; \\
30,39]\end{array}$ & $<0,05$ \\
\hline & $\begin{array}{l}\text { Knowledge of pictogram } \\
\text { meaning: Yes }\end{array}$ & $\begin{array}{l}27 \quad[6,74 ; \\
115,54]\end{array}$ & $<0,05$ \\
\hline & $\begin{array}{l}\text { Storage in specific stores } \\
: \text { Yes }\end{array}$ & $\begin{array}{l}97,6 \quad[38,49 ; \\
247,56]\end{array}$ & $<0,05$ \\
\hline & Storage in room : Yes & $\begin{array}{l}0,16 \quad[0,09 ; \\
0,30]\end{array}$ & $<0,05$ \\
\hline $\begin{array}{l}\text { Knowledge of risks } \\
\text { for human yes Vs No }\end{array}$ & $\begin{array}{l}\text { Storage in specific ware- } \\
\text { house: Yes }\end{array}$ & $\begin{array}{l}0,52 \quad[0,25 ; \\
1,10]\end{array}$ & $>0,05$ \\
\hline
\end{tabular}

\section{Signs of intoxication:}

The most mentioned were skins irritation by $87.5 \%$ of respondents, eye irritation by $51.5 \%$, and loss of appetite by $51.3 \% .93 .8 \%$ of the interviewed had experienced or heard of at least one case of acute pesticide poisoning. $59.6 \%$ of respondents thought that pesticides purchased in the black markets pesticides were more toxic than those purchased through official channels.

\section{Discussion}

The population interviewed in the study was young; the average age which is 36.5 years $( \pm 10.6)$ was similar to the one found in 2012 by Passiani which was 37.7 years $( \pm 12.5)$ in Brazil $^{[6]}$, but a little higher to the one found in Thailand in a Knowledge, attitudes and practices survey, on female workers which was 26.0 years $( \pm 6.8)^{[7]}$. This difference may be due to the fact that the Thailandese study only targeted pregnant women. More than half or $54.6 \%$ of the surveyed people in this study were aged between 21 and 40 years, whereas $87.5 \%$ of the surveyed in our study said they were aged between 18 and 50 years. Almost all the surveyed people were men. Yet, this male trend was also found in the study of Passiani $99.1 \%$ and by other studies carried out by Brazilian authors ${ }^{[8-10]}$. But in their case these results would confirm the profile of Brazilian rural population. A Chinese study on population has found an opposite trend in which women outnumber men ${ }^{[11]}$.

The proportion of illiterate population in our study is much higher than the one found by some authors who reported only $6.3 \%$ illiterates in their studies ${ }^{[6]}$. In the United States more than half pesticides users had at least 12 years schooling and for the same proportions had primary level education in Greece ${ }^{[12,13]}$.
We believe that illiteracy could be a major handicap in identifying pesticides that contain, in addition to pictograms, written instructions in foreign languages.

We didn't noted pesticide of the class I (IA: extremely dangerous and IB: very dangerous). Almost all the pesticides noticed are of class II (moderately dangerous) which was not the case in Brasilia where $46.5 \%$ pesticides registered were of class I. Yet, it should be pointed out that, the dimethoate which is on our list has shown toxicity. That is the reason why it is no more used in some countries ${ }^{[14]}$. Chlopyrifos is reported to account for $31 \%$ of intoxication cases in Brazil ${ }^{[6]}$.

The organophosphates pesticides were rated first among the pesticides with $63 \%$ that cause intoxication, according to Turkish work which states that $94 \%$ of intoxications cases are due to pesticides ${ }^{[15]}$. A Japanese study concluded that organophosphates pesticides causes serious toxicity during acute and chronic exposures ${ }^{[16]}$. All the same, in the United States, organophosphates pesticides were no longer used in order to protect the population health ${ }^{[17]}$.

Identification of pesticides by their labels remains the only means of truly recognizing a pesticide. People should also be to recognize the level of toxicity and human and environmental risks as well as the usage method and precautions. The proportion of the surveyed that were aware of pictograms significance is almost the same as the one found by Passiani $(68.8 \%)$ in his study ${ }^{[6]}$. The same study reports $77.7 \%$ favorable opinions on the facts that pesticides were bad for health. The proportion reported is lower than that of our study. As for air and Water pollution risks, the proportions found are almost the same. Unawareness of the potential toxicity of pesticides purchased at black market represent half of the surveyed could contribute to buying on this market and be an obstacle to mastering the quality of the products circulating in the area. The fight against parasites as the reason of pursuing the usage of pesticides is equally mentioned by $90 \%$ producers in Brasilia ${ }^{[18]}$. We notice bad good behaviors the opposite of what Passiani reported $80 \%$ surveyed had at disposal a special room for pesticides storage whereas only $4.5 \%$ who stored them in their rooms ${ }^{[6]}$. In Au Sri Lanka 33\% households surveyed stored pesticides in their houses. The Storage of shows a total unawareness of the danger pesticides represent and the risks we are exposed to. This availability of pesticides in houses played a great part in the appearance of impulsive acts of autolyse according to a study in Sri Lanka ${ }^{[19,20]}$. The reutilization and sale are the most evoked destinations for the most packages in our study. In Mali it's incineration that comes first with $62 \%{ }^{[21]}$, in Senegal it's abandonment in the farms for $70 \%$ surveyed $^{[21]}$. In all cases as well as in our study none of the surveyed people returned the packages to distribution centers or to specialized offices for their secured management ${ }^{[22]}$. This behavior is not reported by Passiani which indicates that $82 \%$ of his surveyed people declared that they returned the empty packag$\mathrm{es}^{[6]}$. Furthermore, he indicates in the same study that empty packages were found on the farms of those who had declared to have returned them to the collection posts; actually $54.4 \%$ had stored the empty packages in their houses, in some areas and at last $34.8 \%$ had burnt or buried them in the fields ${ }^{[6]}$. The absence of current precautions found mostly with our surveyed is in higher proportions in Senegal $95 \%$, in Ethiopia 76.3\% ${ }^{[23,24]}$. But similar data to ours are reported in Spain $65 \%$ and in Thailand $64.4 \%{ }^{[25,26]}$. 
Literacy and membership to a peasant association were key factors that favored the level of awareness and adoption of good practices. The stake of literacy project is to prepare the younger generation of cotton producers to meet the challenge of professionalization of agriculture. That would lead to the creation of professionalized farmers organizations which would be self dependent and less vulnerable to the influence of capitalistic oligarchy, as is the case now. However, the Brazilian study did not emphasize on literacy and storage of pesticides in specific warehouse $\mathrm{e}^{[6]}$. Like in our study, Konradsen, et al found no link between risk awareness for human health and good storage practices in warehouses dedicated exclusively to pesticides ${ }^{[20]}$.

\section{Conclusion}

The Knowledge, Attitude and Pratice study has shown that although most farmers were aware that pesticides can harm their health, many still have bad behaviors on pesticide handling and management of the empty containers.

Risk factors assessment of pesticides relating to pesticides handling in our study area is dependent on human factors: in terms of risk awareness and good storage practices and handling. Production activities which involve the use of pesticides are not enough organized to offer a frame of training and educational of the various actors. Illiteracy is a major handicap to understanding safety instructions. As a result, we noted practice at risk regarding storage, regarding precaution of use and management of empty containers.

The existence of informal markets for provision of pesticides does not guarantee the toxicological quality of the products used.

Acknowledgments: We thank all the participants for their participation. Also we thank all the structures decentralized of the Ministry of Agriculture, of Breeding and of Fishing.

Conflicts of Interest: None declared

\section{References}

1. International Workshop on Crop Protection Chemistry. 2005

2. Alavadja, M.C., Hoppin, J.A., Kamel, F. Health effect of chronic pesticide exposure: Cancer and neurotoxicity. (2004) Annu Rev Public Health $25: 155-197$.

3. Hervé, N. Multiplication des cas d'intoxication alimentaire au Bénin. (OMS/PNE) 1990.

4. Ton, P. La production du coton biologique en Afrique sub-saharienne: le besoin d'une augmentation à l'échelle. Pesticide Action Network (2002).

5. Badarou, S., Coppieters, Y. Intoxication alimentaire dues à l'endosulfan: mise en place d'un système de notification et de prise en charge au Bénin. (2009) Environnement Risques \& santé 8(2): 133-136.

6. Passiani, J.O., Torres, P., Silva, J.R., et al. Knowledge, Attitudes and Practices and Biomonitoring of farmers and Residents Exposed to Pesticides in Brazil. (2012) Int J Environ Res Public Health 9(9): 3051-

\section{8}

7. Lorenz, N.A., Prapamontol, T., Narsken, W., et al. Pilot study of pesticide knowledge, attitude, and practices among pregnant women in northern Thailand. (2012) Int J Environ Res Public Health 9(9): 33653383

8. Faria, N.M.X., Rosa, J.A.R., Facchini, L.A. Poisoning by pesticides among family fruit farmers, Bento Gonçalves, Southern Brazil. (2009) Rev Saude Publica 43(2): 335-344.

9. Recena, M.C., Caldas, E.D., Pires, D.X., et al. Pesticides exposure in Culturama, Brazil-Knowledge, attitudes and practices. (2006) Environ Res 102(2): 230-236.

10. Waichman, A.V., Eveb, E., Nina, N.C.S. Do farmers understand the information displayed on pesticide product labels? A key question to reduce pesticides exposure and risk of poisoning in Brazilian Amazon. (2007) Crop Pot 26(4): 576-583.

11. Zhang, X., Zhao, W., Jing, R., et al. Work-related pesticide poisoning among farmer in two villages of Southern China: A cross-sectional survey. (2011) BMC Public Health 11: 429-436.

12. Stokes, L., Stark, A., Marshall, E., et al. Neurotoxicyty among pesticide applicator exposed to organophosphates. (1995) Occup Environ Med 52(10): 648-653.

13. Damalas, C.A., Georgiou, E.B., Theodorou, M.G. Pesticide use and safety practices among Greek tobacco farmers: A survery. (2006) Int J Environ Health Res 16(5): 339-348.

14. Merhi, M. Étude de l'impact de l'exposition à des mélanges de pesticides à faibles doses: caractérisation des effets sur des lignées cellulaires humaines et sur le système hématopoïétique murin et sur le système hématopoïétique murin. (2008) Doctorat De L' Universite De Toulouse 140.

15. Kir, M.Z., Oztürk, G., Gürler, M., et al. Pesticide poisoning cases in Ankara and nearby cities in Turkey: An 11 year retrospective analysis. (2013) J Forensic Leg Med 20(4): 274-277.

16. Satoh, T., Hosokawa, M. Organophosphates and their impact on the global environment. (2000) Neurotoxicology 21(1-2): 223-227.

17. Jaga, K., Dharmani, C. Source of exposure to and public health implications of organophosphate pesticides. (2003) Rev Panam Salud Publica 14(3): 171-185.

18. Brazilian Institute of Geography and statistics. Censo Agropécuario 2006.

19. Eddleston, M., Phillips, M.R. Self poisoning with pesticides. (2004) BMJ 328(7430): 42-44.

20. Konradsen, F., van der Hoek, W., Peiris, P. Reaching for the bottle of pesticide-a cry for help. Self-inflicted poisoning in Sri Lanka. (2006) Soc Sci Med 62(7): 1710-1719.

21. Pesticide Action Network Africa: Rapport d'étude sur les pesticides dangereux au Bénin. (2004) 2: 87

22. Agenda Washa. Community Pesticides Monitoring in Ngare Nanyuki. (2007) Final Implementation Report 49.

23. Ngowi, A.V.F., Wesseling, C., London, L. Health impact in Developing Countries. (2007) In Encyclopedia of Pest Management, Pimentel D., Taylor \& Francis: New York 2: 228-231.

24. Karunamoorthi, K., Mohammed, A., Jemal, Z. Peasant association member's knowledge, attitudes, and practices towards safe use of pesticide management. (2011) Am J Ind Med 54(12): 965-970.

25. Garcia, A.M., Ramirez, A., Lacasana, M. Practicas de utilizacion de plaguicidas en agricultores. (2002) Gac Sanit 16(3): 236-240.

26. Jintana, S., Sming, K., Krongtong, Y., et al. Cholinesterase activity, pesticide exposure and health impact in a population exposed to organophosphate. (2009) Int Arch Occup Environ Health 82(7): 833-842. 